\title{
Hubungan antara Literasi Kesehatan dengan Kualitas Hidup pada Penyan- dang Diabetes Melitus Tipe 2 di Rumah Sakit Umum GMIM Pancaran Kasih Manado
}

\author{
Lucyana L. Pongoh, ${ }^{1}$ Karel Pandelaki, ${ }^{2}$ Windy Wariki ${ }^{3}$
}

\author{
${ }^{1}$ Program Studi Magister Ilmu Kesehatan Masyarakat Program Pasca Sarjana Universitas \\ Sam Ratulangi Manado \\ ${ }^{2}$ Bagian Ilmu Penyakit Dalam Fakultas Kedokteran Universitas Sam Ratulangi Manado \\ ${ }^{3}$ Bagian Ilmu Kedokteran Komunitas Fakultas Kedokteran Universitas Sam Ratulangi \\ Manado \\ Email: lucyanaleonita@gmail.com
}

\begin{abstract}
People with diabetes mellitus tend to increase especially in low and middle income countries. Health literacy is an important construct in diabetes care, improvement of quality of life (QoL), and decrease of complications. This study was aimed to analyze the relationship between health literacy and QoL among people with type 2 diabetes mellitus (T2DM) at Gereja Masehi Injili di Minahasa (GMIM) Pancaran Kasih Hospital Manado. This was a descriptive and correlational analytical study with a cross sectional design. The population in this study were all T2DM patients who came for treatment at the Internal Medicine Polyclinic of the GMIM Pancaran Kasih Hospital in the period of November 2019 to February 2020. There were 132 patients as samples in this study. Data were carried out by using the HLS-EU-Q16 and QoL questionnaires, and were analyzed by using the Chi Square test with a significance level of $\mathrm{p}=0.05$. The results showed that of health literacy variable, all respondents (100\%) were easy in terms of literacy, meanwhile of QoL variable, 75.0\% of respondents had good QoL. Moreover, the relationship between health literacy and QoL had a $p$ value of 0.000 . In conclusion, there was a significant relationship between health literacy and the QoL of people with T2DM at the GMIM Pancaran Kasih Hospital Manado.
\end{abstract}

Keywords: literacy, quality of life, people with DM

\begin{abstract}
Abstrak: Penyandang diabetes melitus (DM) di seluruh dunia cenderung meningkat terutama di negara berpenghasilan rendah dan menengah. Literasi kesehatan merupakan konstruksi penting dalam perawatan diabetes, peningkatan kualitas hidup, dan pengurangan komplikasi. Penelitian ini bertujuan untuk menganalisis hubungan literasi kesehatan dengan kualitas hidup penyandang diabetes melitus tipe 2 (DMT2) di RSU Gereja Masehi Injili di Minahasa (GMIM) Pancaran Kasih Manado. Jenis penelitian ialah deskriptif analitik korelasional dengan desain potong lintang. Populasi penelitian ialah seluruh pasien DMT2 yang berobat di Poliklinik Penyakit Dalam RSU GMIM Pancaran Kasih Manado pada periode bulan November 2019 sampai Februari 2020. Jumlah sampel penelitian ialah 132 pasien. Pengumpulan data dilakukan menggunakan kuesioner HLS-EU-Q16 dan Quality of Life. Analisis data penelitian menggunakan uji Chi Square dengan tingkat signifikansi $\mathrm{p}=0,05$. Hasil penelitian menunjukkan bahwa untuk variabel literasi kesehatan, seluruh responden (100\%) mudah dalam hal literasi dan untuk kualitas hidup, 75,0\% responden memiliki kualitas hidup yang baik. Selain itu, hubungan literasi kesehatan dengan kualitas hidup mendapatkan $p=0,000$. Simpulan penelitian ini ialah terdapat hubungan bermakna antara literasi kesehatan dengan kualitas hidup penyandang DMT2 di RSU GMIM Pancaran Kasih Manado,
\end{abstract}

Kata kunci: literasi, kualitas hidup, penyandang DM 


\section{PENDAHULUAN}

Penyandang diabetes (DM) di seluruh dunia telah mencapai sekitar 425 juta orang dan cenderung meningkat terutama di negara berpenghasilan rendah dan menengah. Hasil estimasi International Diabetes Federation (IDF) menyatakan terdapat 629 juta orang menyandang diabetes melitus tipe 2 (DMT2) pada tahun 2045. ${ }^{1}$ Perkumpulan Endokrinologi Indonesia (PERKENI) pada tahun 2015 menyatakan penduduk Indonesia yang menyandang DM mencapai 9,1 juta orang. ${ }^{2}$ Prevalensi DM berdasarkan diagnosis dokter pada penduduk semua usia menurut Riskesdas 2018 telah mencapai 1,5\%, dan Provinsi Sulawesi Utara mencapai $2,3 \% .^{3}$

Diabetes menyebabkan 4 juta kematian dan beban kerugian anggaran kesehatan yang mencapai 727 miliar dolar Amerika Serikat dalam pengeluaran kesehatan pada tahun 2017 atau setara dengan 12\% dari total pengeluaran orang dewasa. Akibat lain dari keadaan DM yang tidak terkontrol yaitu lebih dari 1.106.500 anak hidup dengan DM tipe 1 dan lebih dari 21 juta kelahiran hidup (1 dari 7 kelahiran) dipengaruhi oleh DM selama kehamilan. Risiko ini juga berpeluang dialami oleh 352 juta orang. ${ }^{1,4}$ Penyandang DMT2 tidak dapat sembuh permanen dan bila tidak dikendalikan, maka berisiko mengalami komplikasi seperti peningkatan indeks massa tubuh (IMT), indeks glikemik tidak terkontrol, kelainan fungsi kaki, ginjal, dan kardiovaskuler, serta retinopati. ${ }^{5}$ Komplikasi ini cenderung menunjukkan peningkatan prevalensi setiap tahunnya, bahkan semakin memburuk akibat penyandang DM tidak terlibat aktif mengelola penyakitnya secara mandiri. ${ }^{6}$ Hasil akhir penanganan penyakit kronis selalu bergantung dari tingkat literasi kesehatan penyandang. ${ }^{7}$

Banyak penelitian menyimpulkan bahwa tingkat literasi kesehatan di Asia Tenggara termasuk Indonesia bahkan Provinsi Sulawesi Utara masih sangat rendah, ${ }^{8}$ di dalamnya termasuk literasi kesehatan mengenai DMT2. ${ }^{9-11}$ Literasi kesehatan dan efikasi diri merupakan konstruksi penting dalam perawatan DM, mendukung peningkatan kualitas hidup, dan mengurangi kom- plikasi. Tanpa kemampuan perilaku (pengetahuan dan/atau keterampilan) dalam melakukan tindakan tertentu seperti mengelola glukosa darah, efikasi diri sendiri tidak dapat menghasilkan perilaku perawatan mandiri diabetes yang baik. Interaksi antara literasi kesehatan dan efikasi diri dapat secara positif memrediksi perilaku perawatan kesehatan yang baik. Studi sebelumnya telah menyelidiki peran konstruksi individu pada perawatan diri perilaku dan hasil kesehatan pasien dengan diabetes, ${ }^{4,12}$ namun penelitian mengenai hubungan dan jalur mekanisme antara literasi kesehatan dan efikasi diri masih terbatas. Dalam perawatan DM harus difokuskan pada literasi kesehatan dan efikasi diri, bukan hanya pada konstruksi tunggal. ${ }^{4}$

Literasi kesehatan terbukti berpengaruh besar pada perawatan diri penyandang DM yang juga membawa manfaat sosial dan mendukung pengembangan tindakan sosial dan politik, serta tindakan individu. ${ }^{13}$ Penyandang dengan literasi kesehatan yang tidak adekuat cenderung memiliki kapasitas lebih sedikit untuk melakukan perilaku perawatan diri dibanding pasien yang lebih melek kesehatan, akhirnya mengarah pada hasil klinis yang buruk serta morbiditas dan mortalitas yang lebih tinggi. ${ }^{14}$ Ketidakcukupan literasi kesehatan menjadi penghambat penyerapan informasi kesehatan yang penting dalam perawatan $\mathrm{DM} .{ }^{4}$

Berdasarkan observasi pada pasien yang datang berobat di poliklinik banyak dijumpai pasien DMT2 yang sementara atau sudah menjalani terapi dengan beberapa jenis obat hipoglikemik baik oral maupun insulin yang diinjeksikan, tetapi hasil pemeriksaan gula darah saat kontrol tidak mencapai target yang diharapkan. Sebagian pasien menyatakan bahwa mereka telah melakukan yang terbaik untuk mengontrol gula darah, baik dengan konsumsi obat teratur, diet teratur, bahkan olah raga atau aktivitas yang rutin tetapi tetap saja target gula darah yang diharapkan tidak tercapai. Keadaan ini dapat saja menjadi akibat dari kurangnya literasi dan efikasi diri yang tidak sesuai sehingga menyebabkan perawatan mandiri tidak berjalan baik. 
Secara empiris RSU Gereja Masehi Injili di Minahasa (GMIM) Pancaran Kasih Manado telah menjadi lokasi penelitian DMT2 dan sudah terpublikasi dalam berbagai jurnal kesehatan. Dalam 4 tahun terakhir (sejak tahun 2015) telah diteliti beberapa faktor yang berhubungan dengan kejadian DMT2, ${ }^{15}$ intervensi pengetahuan dengan inisiasi insulin, ${ }^{16}$ pengetahuan dan hipoglikemia, ${ }^{17}$ serta aktivitas dan kualitas hidup. ${ }^{18}$ Data pada bulan Januari sampai Juni tahun 2018 menunjukkan bahwa DMT2 termasuk dalam 10 penyakit yang menonjol dengan jumlah kunjungan pasien rawat jalan sebanyak 3769 kasus artinya terjadi peningkatan jumlah pasien DMT2 sejak tahun 20162018. ${ }^{19}$ Dengan melihat tingginya kunjungan pasien DMT2 dan banyaknya pasien dengan kadar glikemik yang belum terkendali di RSU GMIM Pancaran Kasih maka peneliti tertarik untuk menganalisis hubungan literasi kesehatan dengan kualitas hidup penyandang DMT2.

\section{METODE PENELITIAN}

Jenis penelitian yang digunakan ialah deskriptif korelatif dengan desain potong lintang. Responden mengisi kuesioner (didampingi oleh peneliti) dan menjawab pertanyaan dalam kuesioner health literacy dan Quality of Life (QoL).

Populasi dalam penelitian ini ialah seluruh pasien DMT2 yang berobat di Poliklinik Penyakit Dalam RSU GMIM Pancaran Kasih Manado pada periode bulan November 2019 sampai Februari 2020, yaitu 2.106 pasien. Perhitungan besar sampel menggunakan rumus proporsi binomunal. Untuk mengantisipasi bias akibat jawaban yang tidak lengkap maka dilakukan penambahan sampel yaitu $10 \%$ sehingga jumlah sampel minimal didapatkan 115 pasien. Dari hasil penelitian terkumpul 160 pasien, namun hanya 132 pasien yang memenuhi persyaratan kelengkapan data yang dijadikan sampel.

Variabel penelitian ini meliputi: 1) literasi kesehatan, yaitu kemampuan responden dalam mencari, memahami, menilai, menerapkan informasi kesehatan yang didapatkan dalam kehidupan sehari-hari. Indikator mencari, memahami, menilai, menerapkan, menggunakan alat ukur kuesioner HLS-EU-Q yang terdiri dari 16 soal. Skala data yaitu numerik, dengan kriteria: kurang jika <nilai median 50,00 dan baik jika di atasnya; 2) Kualitas hidup, yaitu penilaian terhadap kesejahteraan hidup berdasarkan nilai-nilai pribadi yang meliputi kesehatan fisik, kepuasan psikologis, serta hubungan individu dengan sosial dan lingkungan yang memengaruhi aktivitasnya sehari-hari. Terdapat empat domain yaitu kesehatan fisik, kesejahteraan psikologis, hubungan sosial, dan hubungan dengan lingkungan. Alat ukur yang digunakan ialah kuesioner QoL. Skala data yaitu numerik dengan kriteria kurang jika di bawah nilai median 46,00 dan kriteria baik jika di atasnya

Analisis data menggunakan bantuan program SPSS dan metode pengujian $C h i$ Square untuk melihat hubungan literasi kesehatan dengan kualitas hidup. Tingkat signifikansi telah ditetapkan $\mathrm{p}=0,05$.

\section{HASIL PENELITIAN}

Tabel 1 memperlihatkan bahwa sebagian besar responden berjenis kelamin perempuan $(68,9 \%)$, berusia $>45$ tahun $(92,4 \%)$, tamat SMA/sederajat $(40,9 \%)$, memiliki pendapatan bulanan $<$ Rp.2.400.000, dan menyandang $\mathrm{DM} \leq 10$ tahun $(89,4 \%)$.

Tabel 2 menunjukkan kategori literasi, yaitu kemampuan responden untuk mencari, memahami, menilai, dan menerapkan informasi kesehatan yang didapatkan dalam kehidupan sehari-hari. Ternyata seluruh responden $(100 \%)$ mudah dalam mencari, memahami, menilai dan menerapkan informasi kesehatan yang mereka dapatkan dalam kehidupan sehari-hari (>47).

Tabel 3 memperlihatkan bahwa untuk variabel kualitas hidup, hasil yang didapat menunjukkan bahwa sebagian besar responden yaitu sebanyak $75,0 \%$ memiliki kualitas hidup yang baik ( $>46)$ sedangkan sebanyak $25,0 \%$ responden memiliki kualitas hidup yang buruk $(\leq 46)$. 
Tabel 1. Karakteristik responden penelitian

\begin{tabular}{lcc}
\hline \multicolumn{1}{c}{ Karakteristik responden } & n & \% \\
\hline Jenis Kelamin & & \\
$\quad$ Laki-laki & 41 & 31,1 \\
$\quad$ Perempuan & 132 & 68,9 \\
Usia & & \\
$\quad \leq 45$ tahun & 10 & 7,6 \\
$\quad>45$ tahun & 122 & 92,4 \\
Pendidikan Terakhir & & \\
$\quad$ Tidak tamat Sekolah Dasar & 3 & 2,3 \\
$\quad$ Tamat Sekolah Dasar & 18 & 13,6 \\
$\quad$ Tamat Sekolah Menengah Pertama & 28 & 21,2 \\
$\quad$ Tamat Sekolah Menengah Atas/ & 54 & 40,9 \\
$\quad$ sederajat & 29 & 22,0 \\
$\quad$ Perguruan Tinggi & & \\
Pendapatan Bulanan & & \\
$\quad$ <p. 2.400.000 & 76 & 57,6 \\
$\quad$ Rp. 2.400.000 & 56 & 42,4 \\
Lama menyandang DM & & \\
$\quad$ >10 tahun & 118 & 89,4 \\
$\quad>10$ tahun & 14 & 10,6 \\
\hline
\end{tabular}

Tabel 2. Kategori skor keseluruhan variabel literasi kesehatan

\begin{tabular}{lcc}
\hline Kategori Literasi & n & \% \\
\hline Sulit & 0 & 0,0 \\
Mudah & 132 & 100,0 \\
Jumlah & 132 & 100 \\
\hline
\end{tabular}

Tabel 3. Kategori kualitas hidup

\begin{tabular}{lcc}
\hline $\begin{array}{c}\text { Kategori } \\
\text { kualitas hidup }\end{array}$ & n & \% \\
\hline Buruk & 33 & 25,0 \\
Baik & 99 & 75,0 \\
Jumlah & 132 & 100 \\
\hline
\end{tabular}

Berdasarkan hasil uji Chi Square didapatkan bahwa literasi kesehatan terkait DMT2 memiliki hubungan bermakna dengan kualitas hidup ( $\mathrm{p}=0,000$; $\mathrm{t}$ hitung $4,546>1,65)$.

\section{BAHASAN}

Hasill penelitian menunjukkan bahwa kemampuan pasien untuk mencari, memahami, menilai, dan menerapkan informasi kesehatan yang didapatkan dalam kehidupan sehari-hari termasuk dalam kategori mudah. Literasi kesehatan merupakan kemampuan individu secara kognitif dan sosial dalam mendapatkan, memroses, dan meng- gunakan informasi kesehatan dalam pengambilan keputusan kesehatan yang akan memengaruhi status kesehatannya di berbagai bidang kehidupan di sepanjang hidup. ${ }^{20}$ Dalam penelitian ini, penilaian terhadap literasi kesehatan dilakukan dengan melihat kemampuan seseorang untuk mencari informasi kesehatan lewat tenaga kesehatan dan media; selanjutnya bagaimana seseorang dapat memahami informasi tersebut, baik yang didapat secara langsung dari dokter atau petugas kesehatan maupun yang didapat dari media; selain itu dilihat juga bagaimana seseorang menilai informasi kesehatan yang dimiliki dalam kehidupan sehari-hari, apakah bisa dipercaya atau tidak, tetapi juga memberi penilaian pada kegiatan sehari-hari yang memengaruhi kesehatan; dan indikator terakhir yang dilihat pada variabel literasi ialah kemampuan untuk menerapkan informasi kesehatan yang diberikan oleh tenaga kesehatan dengan patuh dan juga bagaimana melindungi diri dari penyakit berdasarkan informasi di media.

Banyak faktor yang memengaruhi literasi kesehatan individu, di antaranya ialah usia, jenis kelamin, pendidikan, budaya, bahasa, akses pelayanan, dan akses infor- 
masi kesehatan. ${ }^{20}$ Hasil penelitian ini menunjukkan bahwa semua indikator untuk literasi kesehatan berada pada kategori mudah, artinya pasien tidak mengalami kesulitan pada seluruh indikator. Berbeda dengan penelitian yang dilakukan di Puskesmas Kota Makassar yang menunjukkan hasil tingkat literasi kesehatan yang rendah pada pasien DMT2. Hasil yang rendah dapat disebabkan oleh beberapa faktor misalnya usia dan pendidikan. ${ }^{21,22}$ Seperti yang dijelaskan oleh Nutbeam dan McGill, ${ }^{13}$ bahwa literasi kesehatan menitik-beratkan pada kemampuan membaca, menulis, serta mengakses informasi yang baik. Data penelitian menunjukkan bahwa sebagian besar pasien menempuh pendidikan sampai lulus SMA (40,9\%) bahkan ada yang sampai pada perguruan tinggi (22\%). Pendidikan berperan dalam pembentukan pengetahuan serta keterampilan yang berhubungan dengan kesehatan. ${ }^{23}$ Penelitian oleh Warda ${ }^{24}$ terhadap pasien DMT2 di Rumah Sakit Islam Nahdlatul Ulama Demak juga menyebutkan pada responden berusia manula yang mengenyam pendidikan dasar memiliki pengetahuan yang rendah $(51,0 \%)$, memiliki akses informasi kesehatan rendah $(60,8 \%)$, dan $37,3 \%$ responden memiliki tingkat literasi kesehatan yang tidak memadai. Dalam hal ini, pendidikan juga meningkatkan kemampuan seorang penyandang DMT2 untuk mengumpulkan informasi mengenai penyakitnya, menginterpretasikan informasi kesehatan tersebut yang berdampak pada kesehatannya, dan juga dalam menerapkan setiap informasi kesehatan itu dalam kehidupan sehari-hari untuk menekan risiko penyakit yang disandangnya. Misalnya pasien dengan tingkat pengetahuan tentang penggunaan insulin yang baik dapat mencegah terjadinya hipoglikemia. ${ }^{17}$ Hal yang selaras yaitu hasil penelitian oleh $\mathrm{Dwi}^{25}$ yang mendapatkan bahwa sebagian responden memiliki literasi kesehatan yang tinggi $(56,1 \%)$, dan faktor yang berhubungan dengan literasi kesehatan yaitu usia, bahasa sehari-hari, pendidikan, pekerjaan, penghasilan, dan akses informasi kesehatan.

Untuk variabel kualitas hidup, hasil yang didapat menunjukkan bahwa sebagian besar responden memiliki kualitas hidup yang baik. Penilaian kualitas hidup dalam penelitian ini terdiri dari empat domain: domain 1 yaitu kesehatan fisik, dimana sebagian besar responden masih mampu untuk melakukan aktivitas setiap hari, bekerja, dan bisa tidur dengan baik setiap hari; domain 2 yaitu kesejahteraan psikologis, sebagian besar responden merasa puas terhadap dirinya dan jarang memiliki perasaan negatif seperti kesepian, putus asa dan depresi; domain 3 yaitu hubungan sosial, sebagian besar pasien masih bisa bergaul baik dengan teman-temannya dan orang sekitar, bahkan mendapat dukungan dari mereka; dan domain 4 yaitu hubungan dengan lingkungan, sebagian besar responden merasa puas dengan keadaan lingkungan tempat tinggal saat ini, termasuk akses transportasi sehari-hari.

Hasil penelitian Widhowati et $\mathrm{al}^{26}$ di Kabupaten Sleman Yogyakarta menyatakan bahwa kualitas hidup penyandang DMT2 dalam hal fungsi fisik akan lebih baik pada usia yang lebih muda, tidak memiliki komplikasi penyakit hipertensi, dan melakukan terapi dalam 12 bulan terakhir. Fungsi fisik kualitas hidup penderita DMT2 akan semakin memburuk dengan bertambahnya usia dan terjadinya komplikasi hipertensi, namun kondisi tersebut dapat diperlambat dengan keteraturan berobat. ${ }^{26}$ Orang yang memiliki kualitas hidup baik, dapat juga memiliki kualitas tidur yang baik, dan hal ini dapat membantu seorang pasien mempertahankan kadar gula darahnya. ${ }^{27}$

Kualitas hidup dipengaruhi oleh faktor pengenalan diri sendiri, adaptasi, merasakan perhatian orang lain, perasaan kasih dan sayang, bersikap optimis, mengembangkan sikap empati. Kualitas hidup yang berhubungan dengan kesehatan mencakup dimensi kesempatan, persepsi kesehatan, status fungsional, penyakit, dan kematian; selain itu respon emosi dari pasien terhadap aktivitas sosial, emosional, pekerjaan dan hubungan antar keluarga, rasa senang atau bahagia, adanya kesesuaian antara harapan dan kenyataan yang ada, adanya kepuasaan 
dalam melakukan fungsi fisik, sosial dan emosional serta kemampuan mengadakan sosialisasi dengan orang lain. ${ }^{28}$ Orang yang memiliki pola aktivitas fisik yang baik cenderung memiliki kualitas hidup yang baik pula. ${ }^{18}$

Kualitas hidup yang baik dapat mempermudah proses pengobatan DMT2. Hal ini didukung oleh penelitian oleh Rosyid et $\mathrm{al}^{29}$ terhadap kadar glukosa darah puasa dihubungkan dengan kualitas hidup pada pasien ulkus kaki diabetik yang menyatakan bahwa kualitas hidup merupakan salah satu tujuan utama dalam perawatan, khususnya pada penyandang DMT2. Apabila kadar gula darah dapat terkontrol dengan baik, maka keluhan fisik akibat komplikasi akut ataupun kronis dapat dicegah. ${ }^{30}$ Penelitian oleh Laoh dan Tampongangoy ${ }^{31}$ yang dilakukan di RSUP Prof. Dr. R. D. Kandou Manado juga melaporkan hasil yang sejalan dengan penelitian ini, yaitu sebagian besar penyandang DMT2 (63,3\%) memiliki kualitas hidup yang baik.

Dalam penelitian ini, kualitas hidup bukan hanya berhubungan dengan penyakit DMT2 yang dialami oleh penyandang, tetapi juga berkaitan dengan banyak hal, misalnya keadaan ekonomi, kehidupan bersosial, aktivitas atau kegiatan sehari-hari, transportasi, bahkan juga dalam hal kepuasan penyandang terhadap diri sendiri. Banyak hal yang harus dilakukan oleh seseorang dalam kehidupan sehari-hari, termasuk di dalamnya kehidupan sebagai penyandang DMT2. Masih banyak penyandang DMT2 yang mampu untuk berproduktivitas setiap hari, melakukan aktivitas di dalam maupun di luar rumah, bekerja dan mencari nafkah walaupun sementara menyandang penyakit. Hal-hal tersebut yang dapat membuat kualitas hidup penyandang DMT2 boleh berada pada kategori baik

Literasi kesehatan terkait DMT2 memiliki hubungan bermakna dengan kualitas hidup $(\mathrm{p}=0,000)$, dan pengaruh dari literasi kesehatan terhadap kualitas hidup ialah sebanyak 33,8\%. Kualitas hidup penyandang DMT2 dapat dipengaruhi oleh berbagai macam faktor yaitu faktor demografi yang terdiri dari usia dan status pernikahan, pendidikan, serta faktor medis yang meliputi lama menyandang, komplikasi yang dialami, dan faktor psikologis seperti kecemasan. ${ }^{32}$ Hasil penelitian ini didukung oleh penelitian Nasiriziba et $\mathrm{al}^{33}$ dan Resy ${ }^{34}$ yang menyatakan bahwa usia, pekerjaan, pengetahuan, status perkawinan, derajat luka, dan status ekonomi merupakan faktor yang memengaruhi kualitas hidup. Penelitian Resy $^{34}$ juga menyatakan bahwa faktor jenis kelamin, lama menyandang DM, dan pendidikan berpengaruh terhadap kualitas hidup. Dari hasil-hasil penelitian tersebut dapat disimpulkan bahwa tingkat literasi individu dapat memengaruhi kualitas hidup seorang penyandang DMT2.

Persepsi seseorang tentang kualitas hidupnya, baik untuk kesehatan fisik, kesejahteraan psikologis, hubungan sosial maupun hubungan dengan lingkungan dipengaruhi tentunya oleh faktor-faktor internal yang dimiliki oleh individu tersebut. Dalam hal kualitas hidup penyandang DMT2, literasi kesehatan memengaruhi persepsi penyandang mengenai kualitas hidupnya, misalnya penyandang memiliki pengetahuan yang baik juga akan memengaruhi kualitas hidupnya, demikian pula dari segi pekerjaan. Selain itu, literasi kesehatan akan berdampak pada motivasi seseorang untuk melakukan perawatan kesehatan yang pada ujung-ujungnya akan berpengaruh pada kualitas hidup.

Keterbatasan penelitian ini ialah penilaian terhadap kualitas hidup hanya diukur dari persepsi responden lewat pengisian kuesioner. Diharapkan peneliti selanjutnya dapat melakukan penilaian terhadap kualitas hidup lewat observasi langsung atau melalui validasi orang sekitar.

\section{SIMPULAN}

Terdapat hubungan langsung yang sedang antara literasi kesehatan dengan kualitas hidup penyandang DMT2 di RSU GMIM Pancaran Kasih Manado.

Berdasarkan hasil penelitian ini, disarankan agar pihak rumah sakit turut berperan aktif dalam memfasilitasi tenaga kesehatan mendapatkan informasi mengenai literasi kesehatan dalam usaha untuk mem- 
berikan promosi kesehatan dan pelayanan kesehatan yang lebih baik kepada pasien.

\section{Konflik Kepentingan}

Penulis menyatakan tidak terdapat konflik kepentingan dalam studi ini.

\section{DAFTAR PUSTAKA}

1. Cho NH, Shaw JE, Karuranga S, Huang Y, da Rocha Fernandes JD, Ohlrogge AW, et al. IDF Diabetes Atlas: Global estimates of diabetes prevalence for 2017 and projections for 2045. Diabetes Res Clin Pract. 2018;138:271-81.

2. Perkeni. Konsensus Pengelolaan dan Pencegahan Diabetes Melitus Tipe 2 di Indonesia. Jakarta: PB Perkeni, 2015.

3. Kemenkes RI, KKRI. Hasil Utama Riset Kesehatan Dasar Terintegrasi SUSENAS 2018. Jakarta: Badan Penelitian dan Pengembangan Kesehatan Kemenkes RI, 2018.

4. Xu XY, Leung AYM, Chau PH. Health literacy, self-efficacy, and associated factors among patients with diabetes. Health Literacy Research and Practice (HLRP). 2018;2(2):e67-e77.

5. Zheng Y, Ley SH, Hu FB. Global aetiology and epidemiology of type 2 diabetes mellitus and its complications. Nat Rev Endocrinol. 2018;14(2):88.

6. ADA. Glycemic targets: standards of medical care in diabetes - 2018. Diabetes care. 2018;41(Supplement 1): S55-S64.

7. Berkman ND, Davis TC, McCormack L. Health literacy: what is it? J Health Commun. 2010;15(S2):9-19.

8. Rajah R, Hassali M, Murugiah M. A systematic review of the prevalence of limited health literacy in Southeast Asian countries. Public Health. 2019;167:8-15.

9. Haskas Y, Dewi I. Manajemen Pengendalian Diabetes Mellitus melalui Peningkatan Health Literacy Diabetes. Indonesian Journal of Community Dedication (IJCD). 2019;1(1):1-8.

10. Malik MZ, Musmulyadi M, Mukhtar AT. hubungan health literacy dengan self care manajemen pada pasien diabetes mellitus. Jurnal Ilmiah Kesehatan Pencerah (JIKP). 2019;8(01):1-6.

11. Patandung VP, Kadar K, Erika KA. (2018). Tingkat literasi kesehatan pasien diabetes mellitus tipe 2 di Puskesmas
Kota Tomohon. Jurnal Terpadu Ilmu Kesehatan. 2018;7(2):137-142.

12. Bandura A. Applying theory for human betterment. Perspect Psychol Sci. 2019; 14(1):12-5.

13. Nutbeam D, McGill B. Improving health literacy in clinical and community populations. International Handbook of Health Literacy: Research, Practice and Policy Across the Life-Span, 2019; p. 219.

14. van der Heide I, Uiters E, Rademakers J, Struijs JN, Schuit AJ, Baan CA. Associations among health literacy, diabetes knowledge, and self-management behavior in adults with diabetes: results of a dutch cross-sectional study. J Health Commun. 2014;19(sup2):11531.

15. Palimbunga TM, Ratag BT, Kaunang WP. Faktor-Faktor yang berhubungan dengan kejadian diabetes melitus tipe $2 \mathrm{di}$ RSU GMIM Pancaran Kasih Manado. Media Kesehatan. 2017;9(3).

16. Singal G, Katuuk ME, Bataha YB. Hubungan pengetahuan tentang terapi insulin dengan inisiasi insulin pada pasien diabetes melitus tipe 2 di Rumah Sakit Pancaran Kasih GMIM Manado. Jurnal Keperawatan. 2017;5(1).

17. Pelle C, Pondaag L, Bataha YB. Hubungan pengetahuan penggunaan insulin dengan hipoglikemia pada pasien diabetes melitus di Poli Penyakit Dalam RSU GMIM Pancaran Kasih Manado. Jurnal Keperawatan. 2016;4(2).

18. Timisela JC, Ratag BT, Kalesaran AF. Hubungan aktivitas fisik dengan kualitas hidup pasien dm tipe II di RSU Pancaran Kasih. Media Kesehatan. 2017;9(3).

19. Pangau EE, Katuuk ME, Kallo VD. Hubungan motivasi dengan efikasi diri pada pasien dengan diabetes melitus tipe II di Rumah Sakit Umum GMIM Pancaran Kasih Manado. Jurnal Keperawatan. 2019;7(1).

20. Sabil FA. Hubungan health literacy dan self efficacy terhadap self care management penderita diabetes mellitus tipe $2 \mathrm{di}$ Puskesmas Kota Makassar (Batua, Antang, Bara-Barayya [Tesis\}. Makassar: Universitas Hasanuddin; 2018.

21. Sabil FA, Kadar KS, Sjattar EL. Faktor-faktor pendukung self care management 
diabetes mellitus tipe 2: A literature review. Jurnal Keperawatan. 2019; 10(1):48-57.

22. Ownby RL, Waldrop-Valverde D, Taha J. Why is health literacy related to health? An exploration among US national assessment of adult literacy participants 40 years of age and older. Educational Gerontology. 2012;38(11):776-87.

23. Santosa KS. Faktor-faktor yang berhubungan dengan tingkat kemelekan kesehatan pasien di Klinik Dokter Keluarga Fakultas Kedokteran Universitas Indonesia Kiara, DKI Jakarta Tahun 2012 [Tesis]. Jakarta: Universitas Indonesia; 2012.

24. Warda UA. Faktor-faktor yang berhubungan dengan tingkat health literacy pada pasien diabetes mellitus tipe 2 di Rumah Sakit Islam Nahdlatul Ulama Demak [Undegraduate thesis]. Semarang: Universitas Muhammadiyah Semarang; 2018.

25. Dwi AH. Analisis faktor yang mempengaruhi literasi kesehatan pada penderita diabetes melitus tipe 2 di Puskesmas Kota Padang Tahun 2019 [Diploma Thesis]. Padang: Universitas Andalas; 2020..

26. Widhowati FI, Farmawati A, Dewi FST. Faktor-faktor fungsi fisik kualitas hidup penderita diabetes melitus tipe 2 di Kabupaten Sleman, Yogyakarta: Analisis data HDSS Sleman tahun 20152017. VISIKES. 2020;19(01):98-108.

27. Kurnia J, Mulyadi N, Rottie J. Hubungan kualitas tidur dengan kadar glukosa darah puasa pada pasien diabetes melitus tipe 2 di Rumah Sakit Pancaran Kasih GMIM Manado. Jurnal Keperawatan. 2017;5(1).
28. Gobbens RJ, Remmen R. The effects of sociodemographic factors on quality of life among people aged 50 years or older are not unequivocal: comparing SF-12, WHOQOL-BREF, and WHOQOLOLD. Clinical interventions in aging. 2019;14:231.

29. Rosyid FN, Supratman S, Kristinawati B, Kurnia DA. Kadar glukosa darah puasa dan dihubungkan dengan kualitas hidup pada pasien ulkus kaki diabetik. Jurnal Keperawatan Silampari. 2020;3(2):5009.

30. Setiyorini E, Wulandari NA. Hubungan lama menderita dan kejadian komplikasi dengan kualitas hidup lansia penderita diabetes mellitus. Research Report. 2017:75-82. Seminar Nasional dan Gelar Produk (SENASPRO) 2017.

31. Laoh JM, Tampongangoy D. Gambaran kualitas hidup pasien diabetes mellitus di Poliklinik Endokrin RSUP Prof. Dr. RD Kandou Manado. Jurnal Ilmiah Perawat Manado (Juiperdo). 2015; 4(1):32-7.

32. Roifah I. Analisis hubungan lama menderita diabetes mellitus dengan kualitas hidup penderita diabetes mellitus. Jurnal Ilmu Kesehatan. 2017;4(2):7-13.

33. Nasiriziba F, Rasouli D, Safaei Z, Rokhafrooz D, Rahmani A. Factors associated with quality of life in patients with diabetic foot ulcers. Jundishapur J Chronic Dis Care, 2015;4(1):e26598.

34. Resy PS. Faktor-faktor yang mempengaruhi kualitas hidup pasien diabetes mellitus dengan ulkus diabetikum di RSUP DR. M. Djamil Padang [Diploma Thesis]. Padang: Universitas Andalas; 2018. 